\title{
Metode Pembelajaran Preceptorship dibandingkan dengan Konvensional terhadap Keterampilan Pemeriksaan Kehamilan Mahasiswi Kebidanan
}

\author{
Ari Indra Susanti, ${ }^{1}$ Firman F. Wirakusumah, ${ }^{2}$ Herry Garna ${ }^{3}$ \\ ${ }^{1}$ Departemen Ilmu Kesehatan Masyarakat, Fakultas Kedokteran Universitas Padjadjaran, \\ ${ }^{2}$ Departemen Obstetri dan Ginekologi, Fakultas Kedokteran Universitas Padjadjaran, \\ ${ }^{3}$ Departemen Ilmu Kesehatan Anak, Fakultas Kedokteran Universitas Padjadjaran
}

\begin{abstract}
Abstrak
Salah satu kompetensi utama bidan dalam kurikulum D-III Kebidanan Tahun 2011 yaitu bidan sebagai care provider yang mampu memberikan asuhan kebidanan secara efektif, aman, dan bermutu tinggi bagi perempuan dalam siklus reproduksinya secara komprehensif. Untuk mencapai kompetensi tersebut, maka metode pembelajaran konvensional perlu dikembangkan menjadi metode pembelajaran preceptorship. Tujuan penelitian ini untuk mengukur perbedaan metode pembelajaran preceptorship dengan konvensional terhadap keterampilan pemeriksaan kehamilan mahasiswi kebidanan. Metode penelitian yang digunakan adalah quasi eksperimental design dengan rancangan non randomized control group pretest postest design dengan jumlah sampel sebanyak 108 mahasiswi kebidanan di Prodi Kebidanan FK Unpad dan Poltekkes TNI AU Ciumbeleuit. Penelitian ini dilaksanakan dari bulan Desember 2013 sampai dengan Februari 2014. Pengambilan sampel dilakukan dengan teknik total sampling. Analisis uji beda menggunakan uji Z Mann Whitney. Hasil dari penelitian ini menunjukkan bahwa terdapat perbedaan bermakna keterampilan pemeriksaan kehamilan antara metode preceptorship dengan konvensional $(\mathrm{p}<0.005)$. Berdasarkan hasil penelitian tersebut dapat disimpulkan bahwa metode pembelajaran preceptorship yang dilakukan di lahan praktik dapat meningkatkan keterampilan mahasiswa kebidanan.
\end{abstract}

Kata Kunci: Keterampilan, Konvensional, Metode preceptorship

\section{Learning Method Preceptorship Compared to Conventional on Student's Midwifery Prenatal Skills}

\begin{abstract}
One of the main competencies of midwives in the curriculum of D-III Midwifery in 2011 is midwives are the care provider who are able to provide midwifery care in an effective, safe, and high quality for women in their reproductive cycle in a comprehensive manner. To achieve these outcomes, conventional teaching methods need to be developed into a preceptorship teaching methods. The purpose of this study is to measure the differences in learning methods conventional preceptorship with the skills of antenatal midwifery student. The method used is a quasi-experimental design with the design of non-randomized control group pretest posttest design with a total sample of 108 female students in Midwifery studies program of midwifery faculty and polytechnic Ciumbeleuit Air Force. The research was conducted from December 2013 to February 2014. Sampling was conducted with a total sampling technique. While the analysis of different tests conducted using Mann Whitney $Z$ test. The results showed that there were two differences between applying the conventional and preceptorship methods on student's prenatal care skills $(p<0.005)$. Based on these results it can be concluded that the application of the preceptorship learning method in the practice field can increase prenatal care skills of midwifery students
\end{abstract}

Keywords: Convensional, Preceptorship Learning Method, Skills

Korespondensi:

Ari Indra Susanti, SST., M.Keb

Departemen Ilmu Kesehatan Masyarakat, Fakultas Kedokteran Universitas Padjadjaran

Jl. Prof. Dr. Eyckman No. 38 Bandung 40161

Mobile : 081320037240

Email : ukhti3in1@yahoo.com 


\section{Pendahuluan}

Data dari Dinas Kesehatan di Jawa Barat tahun 2012 menunjukkan cakupan kunjungan pemeriksaan kehamilan Antenatal Care (ANC) minimal 4 kali (K4) tercapai 91,24\%. Rencana Strategi (Renstra) tahun 2014 menetapkan target capaian K4 sebesar 95\%. Hal ini menjadi tantangan bagi tenaga kesehatan terutama bidan. ${ }^{1}$

Sesuai Peraturan Menteri Kesehatan No. 1464/Menkes/Per/X/2010 mengenai kewenangan praktik bidan, maka salah satu profil utama bidan yang tercantum dalam kurikulum D-III Kebidanan tahun 2011 adalah bidan sebagai care provider. Dalam hal ini bidan harus mampu memberikan asuhan kebidanan secara efektif, aman, dan bermutu tinggi bagi perempuan dalam siklus reproduksinya secara komprehensif, termasuk pemeriksaan ANC. ${ }^{2,3}$ Berdasarkan hasil ujian mini ce-x keterampilan mahasiswa semester 5 tentang pemeriksaan kehamilan pada saat Praktik Klinik Kebidanan II di Prodi D-III Kebidanan FK Unpad tahun 2011 ternyata mahasiswa yang masih tidak kompeten sebesar $32 \%$.

Untuk menghadapi kendala tersebut maka diperlukan pengelolaan pembelajaran praktik klinik dengan melakukan kolaborasi kemitraan pendidikan di klinik yang melibatkan pembimbing di institusi dan klinik, siswa, serta universitas dengan menggunakan proses preceptorship yang meliputi bimbingan secara langsung kepada mahasiswa selama praktik dan pencapaian hasil

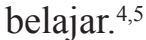

Tujuan penelitian ini untuk mengukur perbedaan metode pembelajaran preceptorship dengan konvensional terhadap keterampilan pemeriksaan kehamilan mahasiswi kebidanan. Berdasarkan fenomena dan data di atas, maka penulis ingin mengadakan penelitian mengenai "Metode pembelajaran preceptorship dibandingkan dengan konvensional terhadap keterampilan pemeriksaan kehamilan mahasiswi kebidanan."

\section{Metode}

Metode penelitian ini dengan menggunakan jenis penelitian quasi experimental design dengan rancangan non randomized control group pretest postest design. Peneliti membandingkan hasil intervensi berupa pengetahuan dan keterampilan dari metode pembelajaran preceptorship (kelompok eksperimen) dengan konvensional (kelompok kontrol) setelah diberikan pretest dan posttest pada kedua kelompok. Penelitian ini dilaksanakan dari bulan Desember sampai dengan Februari 2014. Sampel pada penelitian ini adalah mahasiswi Program Studi D3 kebidanan Fakultas Kedokteran Unpad dan Politeknik Kesehatan TNI AU Ciumbeleuit tingkat 2 semester 3 yang melaksanakan Praktik Klinik Kebidanan. Pengambilan sampel dalam penelitian ini dilakukan dengan menggunakan teknik total sampling. Jumlah sampel untuk kelompok intervensi (dengan metode pembelajaran preceptorship) dan untuk kelompok kontrol (dengan metode konvensional) sebanyak 108 orang.

Kriteria inklusi untuk preceptor pada metode pembelajaran preceptorship, yaitu memiliki pengalaman klinik selama 2-5 tahun, ratio preceptor dengan mahasiswa adalah 1: (2-5) sedangkan preseptor untuk metode pembelajaran konvensional, yaitu bidan sebagai provider di $\mathrm{PKM} / \mathrm{BPM} / \mathrm{RS}$ yang memiliki pengalaman klinik selama 2-5 tahun. Sedangkan kriteria eksklusi untuk preseptor adalah bidan yang tidak memberikan pelayanan di BPM/PKM/RS. Kriteria inklusi pada mahasiswi, yaitu mahasiswi telah lulus ujian teori dan laboratorium untuk pemeriksaan kehamilan, mahasiswi semester III Prodi D-III Kebidanan yang sedang melaksanakan pembelajaran praktik klinik kebidanan dengan kehadiran 100\%. Sedangkan kriteria eksklusi untuk mahasiswi adalah mahasiswi yang sakit atau izin ketika mengikuti pembelajaran Praktik Klinik Kebidanan.

Variabel independen pada penelitian ini, yaitu metode pembelajaran preceptorship, metode pembelajaran konvensional, dan preseptor. Sedangkan variabel dependen, yaitu keterampilan pemeriksaan kehamilan. Variabel perancu pada penelitian ini, yaitu indeks prestasi dan motivasi mahasiswi kebidanan. Analisis data pada penelitan ini merupakan analisis bivariat. Pada skala pengukuran berupa kategorik (ordinal), dengan menggunakan Uji Z Mann Whitney untuk perbedaan metode pembelajaran preceptorship dan konvensional terhadap keterampilan pemeriksaan kehamilan dengan nilai $\mathrm{p}<0.005$.

Aspek dalam etik penelitian ini, meliputi respect for persons (Menghargai harkat dan martabat manusia) dengan memberikan informasi mengenai tata cara/prosedur penelitian dan mengisi informed consent jika bersedia menjadi responden dalam penelitian ini. Kemudian, aspek beneficence and non-maleficence (Bermanfaat dan tidak merugikan). Selain itu juga, aspek justice (keadilan) pada penelitian ini untuk semua responden yang ikut dalam penelitian ini diperlakukan secara adil dan diberikan haknya yang sama. Penilaian keterampilan pemeriksaan kehamilan berdasarkan daftar tilik yang digunakan preseptor, maka responden akan diberikan cenderamata sebagai kompensasi 
waktu dan tenaga yang telah responden berikan. Penelitian ini telah mendapatkan persetujuan dari Komite Etik Penelitian Kesehatan Universitas Padjajaran Fakultas Kedokteran.

\section{Hasil}

Berdasarkan Gambar 1 bahwa keterampilan mahasiswi kebidanan mengenai pemeriksaan kehamilan sebelum diberikan metode pembelajaran preceptorship sebesar 5,2\% yang kompeten dan tidak kompeten sebesar $63,8 \%$ sedangkan sesudah diberikan metode pembelajaran preceptorship sebesar $63.8 \%$ yang kompeten dan tidak kompeten $36,2 \%$. dan Berdasarkan Gambar 2 bahwa keterampilan mahasiswi kebidanan mengenai pemeriksaan kehamilan sebelum diberikan metode pembelajaran kovensional sebesar 18\% yang kompeten dan tidak kompeten $82 \%$ sedangkan sesudah diberikan metode pembelajaran konvensional sebesar $40 \%$ yang kompeten dan tidak kompeten $60 \%$.

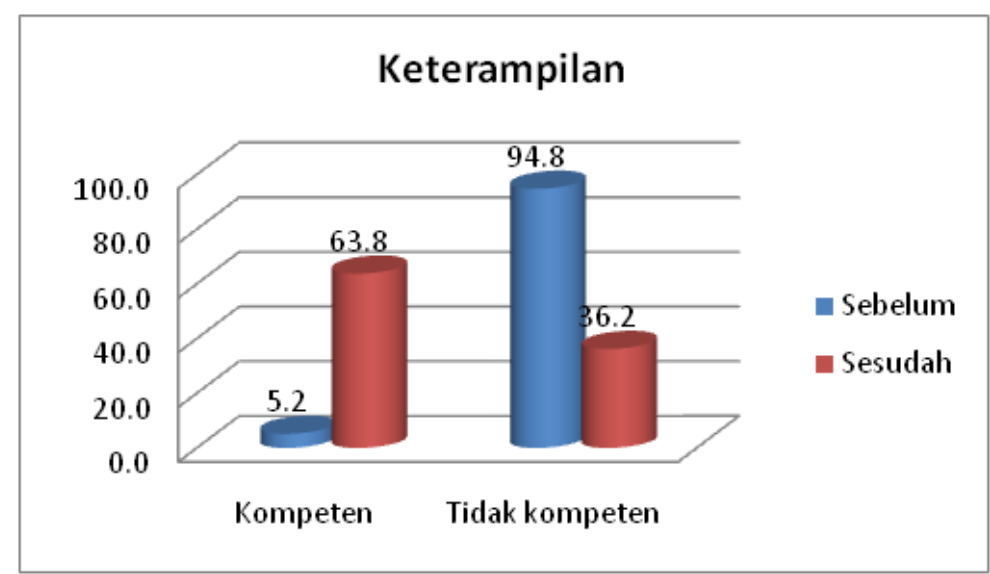

Gambar 1 Perbedaan keterampilan sebelum dan sesudah dilakukan metode pembelajaran preceptorship

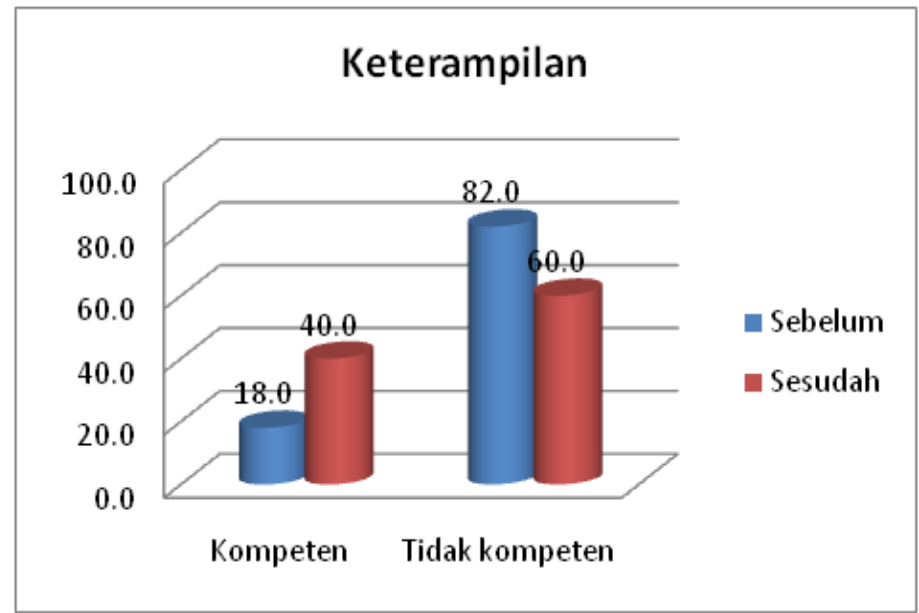

Gambar 2 Perbedaan keterampilan sebelum dan sesudah dilakukan metode pembelajaran konvensional 
Tabel 1 Perbedaan Metode Pembelajaran Preceptorship dengan Konvensional terhadap Keterampilan Pemeriksaan Kehamilan pada Mahasiswi kebidanan.

\begin{tabular}{lcccc}
\hline \multirow{2}{*}{ Variabel } & \multicolumn{2}{c}{ Kelompok Pembelajaran } & & Nilai p \\
\cline { 2 - 3 } & $\begin{array}{c}\text { Preceptorship } \\
(\mathbf{n}=\mathbf{5 8})\end{array}$ & $\begin{array}{c}\text { Komvensional } \\
(\mathbf{n}=\mathbf{5 0})\end{array}$ & ZM-w & \\
\hline Keterampilan & 3,948 & 1,380 & $-4,989$ & 0,000 \\
\hline
\end{tabular}

Ket: Uji Z Mann Whitney

Dari tabel 1 terdapat perbedaan bermakna keterampilan pemeriksaan kehamilan antara metode preceptorship dan konvensional $(\mathrm{p}=0,000)$.

\section{Pembahasan}

Berdasarkan Gambar 1 bahwa keterampilan mahasiswi kebidanan mengenai pemeriksaan kehamilan sebelum diberikan metode pembelajaran preceptorship sebesar 5,2\% yang kompeten sedangkan sesudah diberikan metode pembelajaran preceptorship sebesar $63.8 \%$ yang kompeten. Untuk mencapai pemahaman preceptorship sebagai proses pembelajaran maka preceptor membutuhkan kompetensi andragogik dalam proses preceptorship yang berlangsung di lingkungan belajar untuk membuat hubungan interaktif antara preceptor dan preceptee menjadi bermakna. Selama proses preceptorship maka preceptor memerlukan strategi pendidikan untuk meningkatkan keterampilan dan berpikir kritis dalam pemecahan masalah. Hal ini mendukung kemampuan siswa untuk menerapkan teori umum berupa pengetahuan yang berpusat pada masalah pasien sampai dengan merawat dalam setiap konteks yang spesifik. ${ }^{6}$

Metode pembelajaran preseptorship merupakan tanggung jawab bersama antara institusi pendidikan kebidanan dan rumah sakit untuk menjembatani kesenjangan antara teori dan praktik. Preceptorship ini dimaksudkan untuk memfasilitasi masa transisi mahasiswa dalam meningkatkan kompetensi dan kepercayaan diri. Peran preceptor sebagai role model merupakan salah satu strategi pembelajaran paling efektif yang digunakan dalam program preceptorship. ${ }^{7}$

Hasil penelitian yang dilakukan di Unversitas Toronto di Canada menggunakan metode kualitatif dengan melakukan wawancara dan kelompok diskusi terhadap preceptor dan preceptee, didapatkan manfaat penggunaan model preceptorship, yaitu preceptee memiliki pengalaman yang positif, meningkatkan kepercayaan diri, pengetahuan, dan keterampilan yang terintegrasi dengan situasi kehidupan nyata. ${ }^{8}$ Preceptorship juga dapat membantu preceptor untuk meningkatkan efektivitas mengajar dan menciptakan lingkungan belajar yang efektif sehingga preceptee dapat melakukan keterampilan klinis untuk meningkatkan kualitas pendidikan. ${ }^{9}$ Penelitian yang dilakukan di Botswana untuk menggambarkan pandangan preceptor dan preceptee mengenai peran pembimbing dalam perencanaan kegiatan pembelajaran klinis, sehingga preceptee dapat mencapai tujuan pembelajaran. Didapatkan hasil bahwa preceptor harus fokus pada perannya secara profesional untuk memberikan kesempatan belajar dalam keterampilan yang berbasis bukti yang berorientasi pada unit untuk preceptee selama di klinik. ${ }^{10}$

Berdasarkan Gambar 2 bahwa keterampilan mahasiswi kebidanan mengenai pemeriksaan kehamilan sebelum diberikan metode pembelajaran kovensional sebesar $18 \%$ yang kompeten sedangkan sesudah diberikan metode pembelajaran konvensional sebesar $40 \%$ yang kompeten.

Metode pembelajaran konvensional adalah metode pembelajaran tradisional atau disebut juga dengan metode ceramah, karena sejak dulu metode ini telah dipergunakan sebagai alat komunikasi lisan antara guru dan anak didik dalam proses belajar serta pembelajaran. ${ }^{11} \mathrm{Pada}$ saat kuliah dengan mendengarkan ceramah, mahasiswa akan kesulitan untuk mengikuti atau menangkap makna esensi materi pembelajaran, sehingga kegiatannya sebatas membuat catatan yang kebenarannya diragukan. Pola proses pembelajaran dosen aktif dengan mahasiswa pasif ini efektivitasnya rendah dan tidak dapat menumbuhkembangkan proses partisipasi aktif dalam pembelajaran. ${ }^{12}$

Metode pembelajaran konvensional di klinik, yaitu rangkaian interaksi antara mahasiswa dan pembimbing dalam pembelajaran di klinik dengan model bimbingan lama dalam rangka mencapai kompetensi. ${ }^{13}$ Berdasarkan Tabel 1 . terdapat perbedaan metode pembelajaran preceptorship dengan konvensional terhadap keterampilan 
dengan nilai ZM-w $-4,989$ dan nilai $\mathrm{p}<0,05$. Perbedaan penerapan model pembelajaran preceptorship dengan konvensional berdasarkan optimalisasi komponen/kondisi dalam proses belajar mengajar di klinik yang berbeda, seperti tempat praktik yang menunjukkan situasi dan keadaan fisik (tempat belajar) serta proses bimbingan itu sendiri, meliputi pembimbing/ preceptor, metode pembelajaran, teknik mengajar, evaluasi, dan program pelaksanaan praktik klinik. $^{14}$

Hasil penelitian ini didukung oleh penelitian yang dilakukan di Amerika mengenai perbandingan antara metode pembelajaran konvensional dan preceptorship. Didapatkan hasil bahwa tidak terdapat perbedaan yang signifikan antara kelompok preceptorship dan kelompok konvensional terhadap pengetahuan sedangkan untuk keterampilan juga, didapatkan kelompok preceptorship melakukan keterampilan tidak lebih daripada kelompok konvensional. ${ }^{15}$ Berdasarkan penelitian yang dilakukan di Canada bahwa pengetahuan dan persiapan mengajar berasal dari penelitian yang berbasisi bukti dengan menggunakan desain kualitatif didapatkan hasil bahwa preceptor diberikan kesempatan untuk melakukan persiapan mengajar yang baik, dalam proses pelaksanaan dan juga umpan balik. Selain itu, juga menghasilkan bukti empiris yang dapat memberikan kontribusi substansial untuk persiapan preceptor yang efektif, mempromosikan praktik pengajaran yang terbaik dalam pengaturan klinis, dan juga meningkatkan pengalaman klinis dalam preceptorship. ${ }^{16}$

Keterbatasan pada pada penelitian ini bahwa pelatihan preceptor sangat memengaruhi peran preceptor dalam melakukan bimbingan di klinik. Pada saat melaksanakan pelatihan preceptor terdapat pretest dan posttest serta role play tetapi evaluasi peserta pelatihan preceptor di lahan praktik tidak dapat dilakukan karena keterbatasan pelatih preceptor, biaya, dan juga waktu.

Simpulan dari penelitian ini bahwa metode pembelajaran preceptorship yang dilakukan di lahan praktik dapat meningkatkan keterampilan mahasiswa kebidanan. Saran untuk penelitian ini adalah untuk lahan praktik yang digunakan untuk praktik mahasiswa, dapat menyiapkan preceptor baik dari institusi pendidikan dan juga lahan praktik dengan melakukan pelatihan preceptor selama 1 minggu dengan in job training dalam membimbing mahasiswa di lahan praktik.

\section{Daftar Pustaka}

1. KIA Kemkes RI. Profil Kesehatan Provinsi Jawa Barat. Jakarta: Pusat Data dan Informasi
Kementerian Kesehatan Republik Indonesia; 2012

2. Permenkes Nomor $1464 /$ Menkes/Per/X/2010 tentang Izin dan Penyelenggaraan Praktik Bidan. Jakarta: Menteri Kesehatan RI; 2010.

3. Pusdiklatnakes. Kurikulum Diploma III Kebidanan 2010. Jakarta: Badan PPSDMN Kemenkes RI; 2010.

4. International Confederance of Midwifery (ICM) Council. Model Curriculum Outlines for Professional Education Midwifery. Netherlands: ICM; 2011.

5. Skinner JRM. Mentorship, preceptorship and clinical supervision: three key processes for supporting midwives. New Zealand College of Midwives J. 2008 Oct;39:7-11.

6. Newman CW. Becoming a better preceptor: the clinic as classroom. Hearing J. 2011;64(7):10-8.

7. International Confederation of Midwives (ICM). Global Standards for Midwifery Education. Netherland:Companion Guidelines ICM; 2010.

8. California State University Fullerton (CSUF) Manual Spring Preceptor handbook. Fullerton: Departement of Nursing; 2011.

9. Carlson E. Precepting and symbolic interactionism-a theoritical look at preceptorship during clinical practice. Advanced Nursing J. 2013;69(2):457-64.

10. Brathwaite AC, Lemonde M. Team preceptorship model: a solution for students clinical experience. Nursing Research and Practice J. 2011 March;2011:1-7.

11. Smith C, Swain A, Penprase B. Congruence of perceived effective clinical teaching characteristics between students and preceptors of Nurse Anesthesia Programs. AANA J. 2011;79(4):62-8.

12. Ownby K, Schumann R, Dune L, Kohne A. A comparison of a traditional clinical experience to a precepted clinical experience for baccalaureate-seeking nursing students in their second semester. Nursing Research and Practice J. 2012 Feb;2012:1-6.

13. Hidayat A, Rasyad AS, Anwar AD. Penelitian tentang perbedaan pencapaian kompetensi asuhan persalinan kala II mahasiswa antara model pembelajaran praktik preceptorship dengan konvensional (Tesis). Yogyakarta: STIKes Aisyiah; 2008.

14. Wahyuni A, Ulfah M, Warneri. Perbedaan penerapan model pembelajaran berbasis portofolio dengan metode pembelajaran konvensional terhadap hasil belajar ekonomi (Skripsi). Pontianak: Program Studi Pendidikan Ekonomi FKIP Untan; 2013.

15. Monareng LV, Jooste K, Dube A. Preceptor 
Ari Indra Susanti : Metode Pembelajaran Preceptorship dibandingkan dengan Konvensional terhadap Keterampilan Pemeriksaan Kehamilan Mahasiswi Kebidanan

and preceptee views on student nurses clinical accompaniment in Bostwana. Africa Journal Nursing and Midwifery. 2009;11(2):115-29.

16. Ford K, Fitzgerald M,Courtney-Pratt H. The development and evaluation of a preceptorship program using a practise development approach. Australian J. Advanced Nursing. 2013;30(3):5-13. 